\title{
A new age to an old site: the earliest Tupiguarani settlement in Rio de Janeiro State?
}

\author{
RITA SCHEEL-YBERT ${ }^{1}$, KITA MACARIO ${ }^{2}$, ANGELA BUARQUE ${ }^{3}$, \\ ROBERTO M. ANJOS ${ }^{2}$ and MARIANA BEAUCLAIR ${ }^{1}$ \\ ${ }^{1}$ Departamento de Geologia e Paleontologia, Museu Nacional, UFRJ, Quinta da Boa Vista, São Cristóvão \\ 20940-040 Rio de Janeiro, RJ, Brasil \\ ${ }^{2}$ Instituto de Física, Universidade Federal Fluminense, Av. Gal. Milton Tavares de Souza s/n, Niterói \\ 24210-346 Rio de Janeiro, RJ, Brasil \\ ${ }^{3}$ Departamento de Antropologia, Museu Nacional, UFRJ, Quinta da Boa Vista, São Cristóvão \\ 20940-040, Rio de Janeiro, RJ, Brasil \\ Manuscript received on August 29, 2007; accepted for publication on August 20, 2008; \\ presented by JUAREZ R.B. LOPES
}

\begin{abstract}
This paper presents unexpectedly early dates for a Tupiguarani settlement in Southeastern Brazil. One radiocarbon dating of $1740 \pm 90 \mathrm{yr}$ BP (1820-1390 cal yr BP) was already available for the Morro Grande site (Araruama, southeastern coast of Rio de Janeiro State). Two new dates, obtained from charcoal samples, are reported here. An age of $2920 \pm 70$ yr BP (3220-2790 cal yr BP) was obtained from a specialized hearth, probably used for cooking ceramics; a funerary hearth at the same archaeological locus was dated at $2600 \pm 160 \mathrm{yr}$ BP (3000-2150 cal yr BP). Both measurements were made independently, in different laboratories, arguing for their validity. These results considerably age the arrival time of Tupiguarani populations to the coastal region of Southeastern Brazil. They may have important implications to the hypotheses about the origin and dispersion of these populations from Amazonia, supporting the claim of recent authors who consider that their expansion must have begun well before $2000 \mathrm{yrs}$ BP.
\end{abstract}

Key words: radiocarbon dating, prehistoric occupation, Archaeology, Tupiguarani, Brazil.

\section{INTRODUCTION}

Tupi agriculturalist and ceramist populations share a linguistic stock encompassing different related languages spread throughout the east of South America (Brazil, Peru, Bolivia, Paraguay, Argentina, and Uruguay). Tupinambá and Guarani are the better known of these groups, as they inhabited the Brazilian coast (at the Southeastern/Northeastern and in Southern Brazil, respectively) when Europeans arrived in the XVI century.

It is not trivial to establish direct relations between linguistic manifestations and the archaeological record, but Brazilian archaeologists usually associate the groups

Correspondence to: Rita Scheel-Ybert

E-mail: scheelybert@mn.ufrj.br that produced a typical polychromic ceramics to Tupian languages speakers (Prous 1992, Heckenberger 1998). This attribution is essentially based on historic descriptions of the material culture and funerary ritual of Tupinambá and Guarani populations, which are similar to those found in prehistoric archaeological sites. However, this attribution is not straightforward, so most researchers employ the term "Tupi-Guarani" to refer to historically known groups, and "Tupiguarani" to those known only from archaeological records (Prous 1992).

Several hypotheses have already been presented to explain the processes of origin and dispersion of these populations. Presently, there is consensus in that a common center of origin existed, from which the Tupi fanned out, differentiating through distinct historic and cultural 
processes whilst keeping several common cultural features (Noelli 1998). Most authors agree in situating this center in Amazonia (Rodrigues 1964, 2000, Lathrap 1970, Brochado 1989, Scatamacchia 1990, Dias 1994/ 1995, Noelli 1998, Heckenberger et al. 1998), but there is no agreement regarding where it was located and the direction taken by the expansion routes (Brochado 1989, Fausto 1992, Dias 1994/1995, Urban 1996, Viveiros de Castro 1996, Noelli 1998, Heckenberger et al. 1998).

There are divergences concerning the chronology of the Tupian expansion as well. The history of this expansion has traditionally relied on linguistic, ethnographic (historical distribution of Tupian speakers), and archaeological evidence (pottery seriation, radioisotopic dating). Linguistic and ethnographic data are usually regarded as more accurate, due to the scarcity of archaeological research, especially in Amazonia (Heckenberger et al. 1998). The most widely accepted studies suggest that proto-Tupi (language in which the components of the Tupian stock originated) was formed around 5000 years BP, and the Tupi-Guarani family around 2500 years ago (Rodrigues 1964, 2000), even though some authors argue for a later time (e.g. Migliazza 1982, Urban 1996). Most researchers agree in that Tupi populations couldn't have left Amazonia before that time.

However, absolute dates do not support this hypothesis, as these now make clear that Tupiguarani populations were already settled in their historically known territories at least as early as 2000 years BP (Noelli 1998). In the last years, the multiplication of radiocarbon and thermoluminescence measurements is gradually pulling back the initial occupations. The earliest Guarani supposed ancestrals' occupation in Southern Brazil was dated at 2010 \pm 75 yr BP (Noelli 1999/2000). The earliest known Tupinambá supposed ancestrals' settlements come from São Paulo State: a site from Tietê valley was dated at 2200 yr BP (TL), and sites from the Paranapanema valley were dated at $2030 \pm 200,1870 \pm 100$, and $1660 \pm 170 \mathrm{yr}$ BP (Moraes 2007). In the Northeast, an early age of $1690 \pm 110 \mathrm{yr}$ BP was presented for Piauí State (Maranca 1976).

A radiocarbon measurement previously published for Morro Grande site, of $1740 \pm 90 \mathrm{yr}$ BP (Buarque 1995), already made of it the earliest known Tupiguarani occupation in Rio de Janeiro State. This paper presents even earlier dates for this site, pulling the initial occupation of the Brazilian coast yet further back.

\section{MATERIALS AND METHODS}

The studied area is located in the Araruama region, southeastern coast of Rio de Janeiro State ( $22^{\circ} 47^{\prime} 07^{\prime}$ 'S, $\left.42^{\circ} 21^{\prime} 49^{\prime \prime} \mathrm{W}\right)$ (Fig. 1). Morro Grande site is placed in the homonym district, covering an area of about $90,000 \mathrm{~m}^{2}$ that includes the local school patio and the church plaza.

Archaeological excavations, made along several stages of field work since 1993, identified five stratigraphic layers in different loci. The occupation level attains $0,60 \mathrm{~m}$ of thickness, within a sandy substratum. Most archaeological artefacts (ceremonial and daily-use bowls, upper portion of urns, and lids) occur between $0.20 \mathrm{~m}$ and $0.50 \mathrm{~m}$ of depth, in a grey layer with black lenses of charcoal originated from archaeological hearths. Below this depth (to 1,20 m), within clay and quartz beds, the vestiges are restricted to funerary urns, buried in pits and, generally, well preserved (Fig. 2). The lids are usually broken; their fragments are found interspersed with sediments inside the urns. Painted bowls usually surround the urns. Although the site surficial layer was partially destroyed by urbanization, many intact archaeological features and well preserved ceramics were found. All vestiges are unquestionably related to a Tupiguarani settlement (Buarque 1999).

The site was carefully excavated according to acknowledged archaeological methods. Charcoal from hearths was systematically collected and kept for anthracological analysis or radiocarbon dating. A large charcoal sampling of dispersed (in the sediments) and concentrated (in hearths and other features) material was performed during the 1995 fieldwork, aiming anthracological studies. For that, all the sediments removed from the excavation area were dry- or water-sieved and charcoal pieces were collected with supple tongs.

Two charcoal samples from the same archaeological locus, near to the school building, were dated. This locus presented an important funerary feature and several hearths (Fig. 3).

Gif-11045 sample was collected from a profile at the western side of the excavation area at 30-40 cm depth and measured at the C-14 Laboratory at Gif-sur-Yvette 


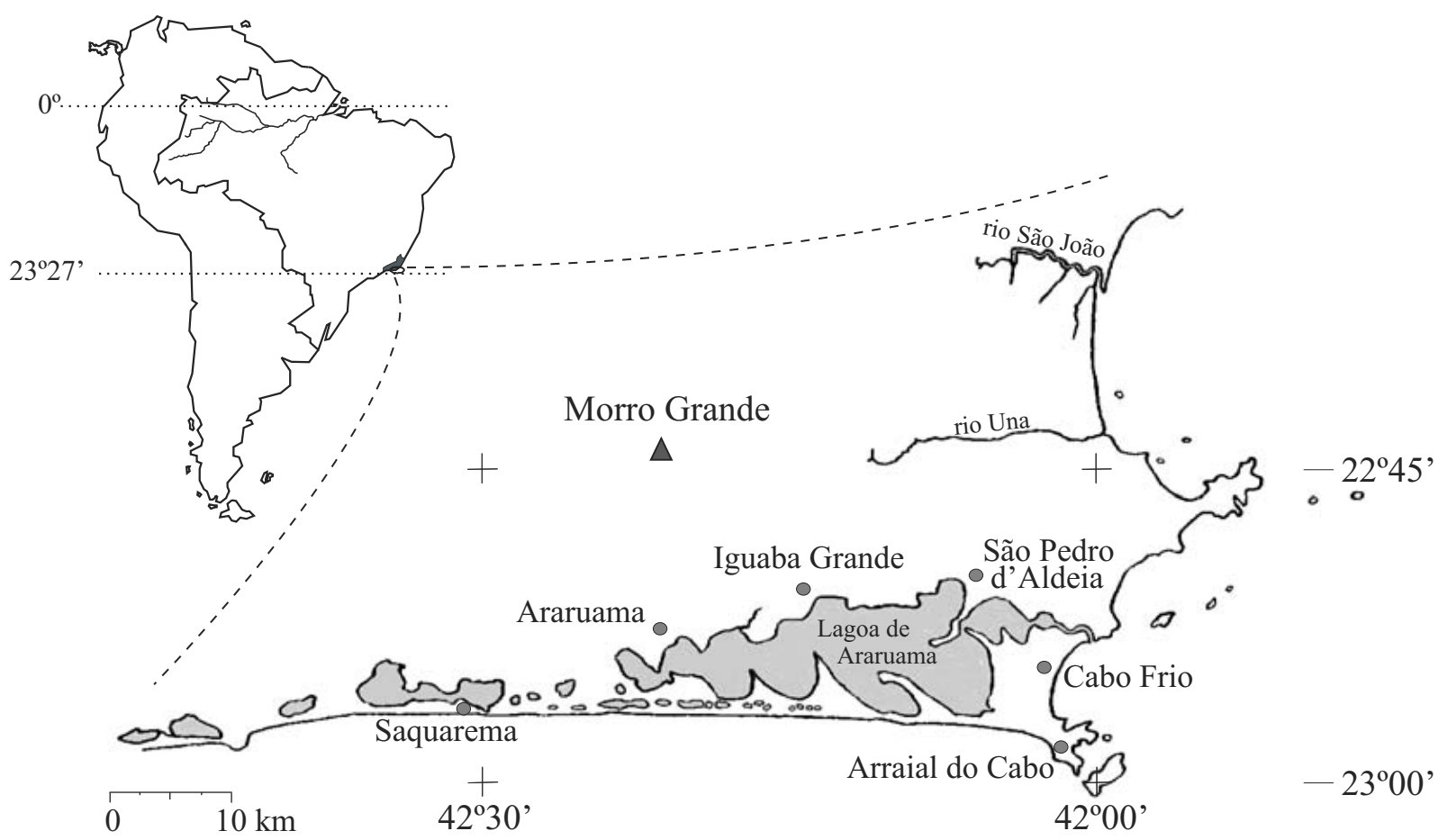

Fig. 1 - Geographical location of the study area.

(France). Plid-0688 sample, collected from a hearth on the eastern side of the excavation area at 30-40 $\mathrm{cm}$ of depth, was prepared and dated at the PRIME Lab of Purdue University (United States). This hearth, along with six other hearths from the same locus, are concentrically distributed around the urn (Fig. 3). They are clearly associated to the funerary structure, the upper part of which is situated at a $30-35 \mathrm{~cm}$ depth.

Radiocarbon measurements were calibrated with OxCal version 3.10 code (Ramsey 1995), using the Southern Hemisphere samples calibration dataset (McCormac et al. 2004). Previous dating was also calibrated for comparison. All results are presented with 2 sigma confidence intervals ( $95.4 \%$ probability).

The remaining charcoal pieces were analyzed under a reflected light brightfield/darkfield microscope, along fresh hand-broken surfaces. Systematic determinations were helped by a computerized key for wood determination associated to a database of anatomical characters for Brazilian species, by comparison with a comparative collection, and by consultation of the specialized literature (cf. Scheel-Ybert 2004b).

\section{RESULTS AND DISCUSSION}

Radiocarbon age for Gif-11045 sample, obtained at first in 1998, is $2920 \pm 70 \mathrm{yr} \mathrm{BP}(3220-2790 \mathrm{cal} \mathrm{yr} \mathrm{BP})$, and that of Plid-0688 sample, obtained in 2002, is $2600 \pm$ 160 yr BP (3000-2150 cal yr BP). These results were initially considered suspicious, as they were much too old in regard to the previous dating of this site (Fig. 4), as well as to the currently assumed chronology for the Tupiguarani earlier occupations.

The fact that both measurements were made independently, in different laboratories, argues for their validity. Moreover, the anthracological analysis of all charcoal samples from this site revealed that Plid-0688 sample corresponded to a bark hearth undoubtedly of anthropogenic origin, and that Gif-11045 sample also contained a great proportion of bark, which cannot be attributed either to dispersed charcoal or to natural origins (M. Beauclair, unpublished data, R. Scheel-Ybert, unpublished data). The incidence of a few bark fragments is expected in anthracological samples, either in natural as in anthropogenic contexts, as this material is not ordinarily taken off when wood is burnt. High proportions of 

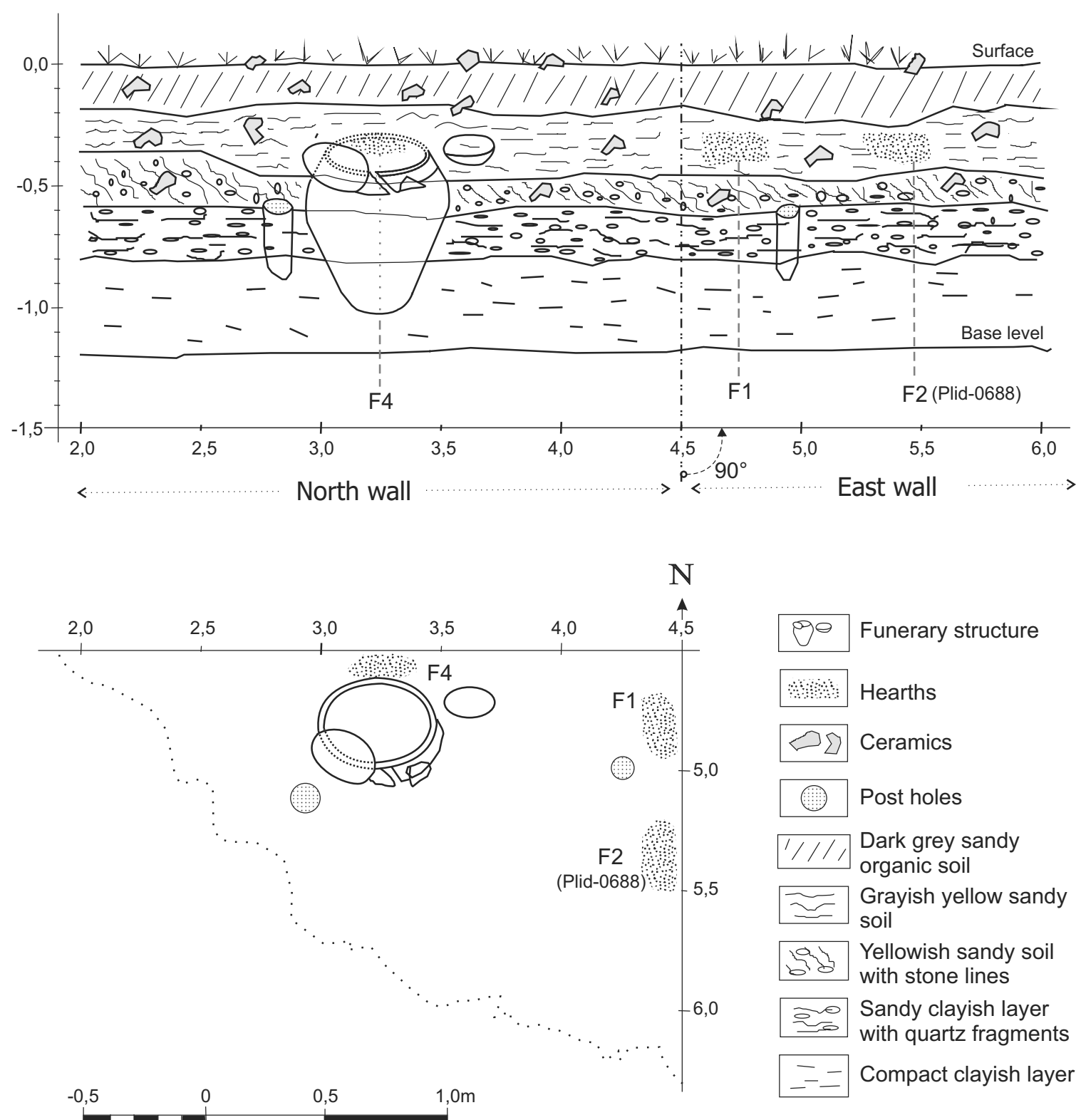

Scale 1:25

Fig. 2 - Schematic stratigraphic profile of north and east walls from Sector 2, Morro Grande archaeological site, and partial surface plan of the same area.

bark, however, cannot occur in natural contexts, because plants always consist of much more wood than bark. It is clear, in the present case, that bark itself was burnt, and that this material has been intentionally selected as fuel.

Wood taxa identified in Plid-0688 attain only 15\% of the sample, corresponding to Bauhinia sp, Copaifera sp, Machaerium sp, and a Sapotaceae. In Gif-11045 sample, wood taxa represent less than $40 \%$ of the fragments, with an extremely high proportion of Copaifera sp. Minor taxa also identified were: Anacardiaceae/ Burseraceae, Chrysobalanaceae, Croton sp, Bauhinia sp, Cassia sp, Dalbergia sp, Machaerium sp, Myroxylon sp, Leguminosae, and Qualea sp.

Utilitarian, domestic, or ritual attribution of these 


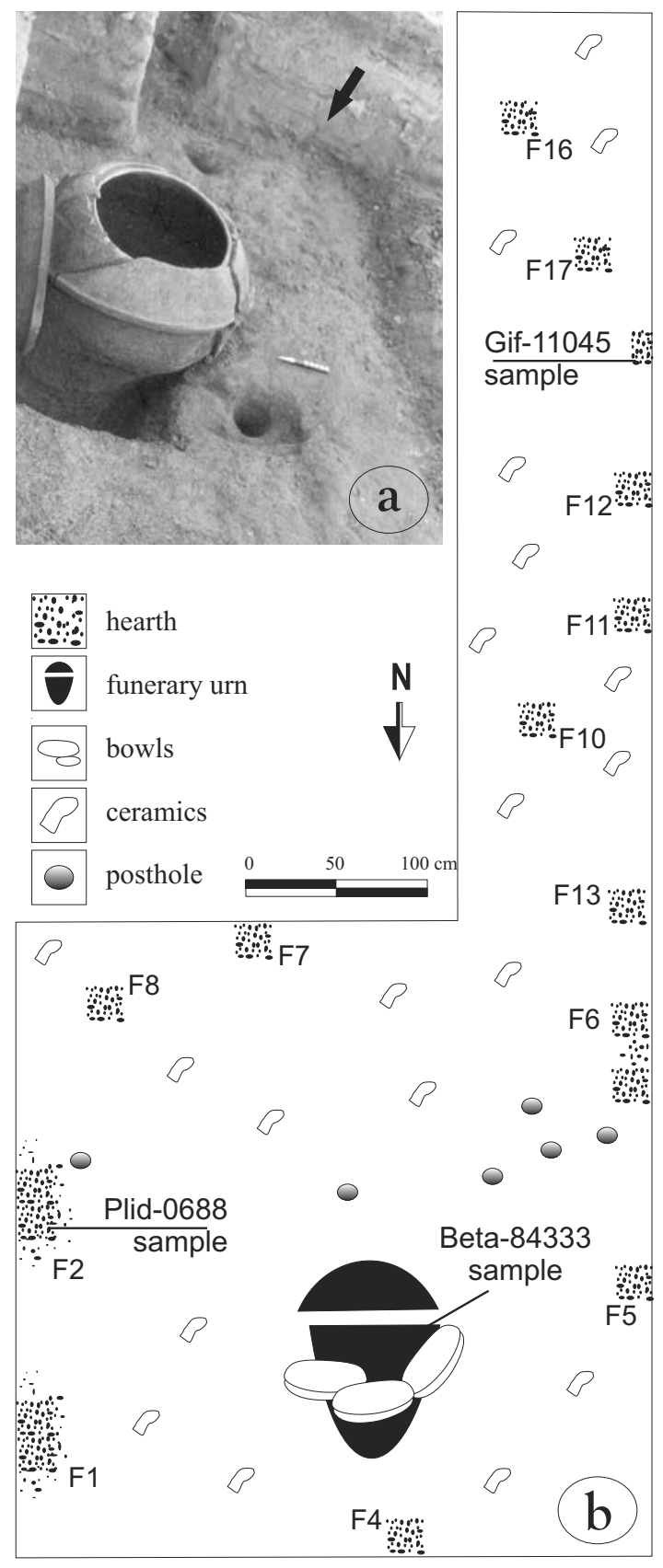

Fig. 3 - Morro Grande site Archaeological Sector 2. (a) View of the excavation area. The arrow indicates the ceremonial hearth from which sample Plid-0688 was taken; (b) Excavation plan situating the excavated hearths, the samples dated in this work (Gif-11045, Plid0688), and a previously dated sample (Beta-84333, Buarque 1995). Hearths F1 to F8, containing high proportions of bark, are interpreted as elements of the mortuary ritual. Hearths F10 to F17, containing few or no bark fragments, are interpreted as domestic features (M. Beauclair, unpublished data). hearths were thoroughly discussed considering their taxonomic composition, archaeological contextualization, and ethnographic analogies (M. Beauclair, unpublished data). A ceremonial function was proposed to Plid-0688 hearth, as well as to the other hearths concentrically distributed around the urn (Fig. 3), all of them containing a very high proportion of bark. Gif-11045 sample, however, is not associated with the funerary structure. Using ethnographic and ethnologic analogy, it was suggested as a probable specialized feature for firing ceramics.

The archaeological contextualization of both dated samples, and their unequivocally association with human activities imposes that such an early period for the Tupiguarani occupation in this region be considered.

Radiocarbon calibrated ages of 3220-2790 cal yr BP (Gif-11045) and 3000-2150 cal yr BP (Plid-0688) could possibly be contemporaneous, but we do not believe they represent precisely the same moment in time. The age of 3220-2790 cal yr BP is associated to a utilitarian feature, probably for ceramics cooking, while the age of 3000-2150 cal yrs BP is clearly related to the funerary ritual. Their spatial proximity suggests the former event is somewhat older than the latter. Probability distributions for the calibrated ages corroborate this idea. Despite the intersection in the calibration intervals, the two samples are most likely not contemporaneous (Fig. 4).

The age previously presented for this site, of 1740 \pm 90 yr BP (1820-1390 cal yr BP), was obtained by the Beta Analytic Laboratory (United States) from charcoal collected inside a funerary urn at the same archaeological locus. This age was considered representative of the mortuary ritual (Buarque 1995). However, the age of $2600 \pm 160 \mathrm{yr}$ BP (3000-2150 cal yr BP) from a funerary hearth associated to this urn contradicts such hypothesis, demonstrating that the mortuary ritual itself was in reality much older.

In fact, charcoal retrieved inside a urn cannot be contemporaneous of the burying. This charcoal certainly came with the sediments deposed subsequently, which fell into the urn at a later time, after its lid was broken.

Anthracological analysis of charcoal collected inside this urn revealed a high taxonomic diversity. Twenty-five wood taxa were identified (Anacardiaceae/ Burseraceae, Annonaceae, Aspidosperma sp, Jacaranda 


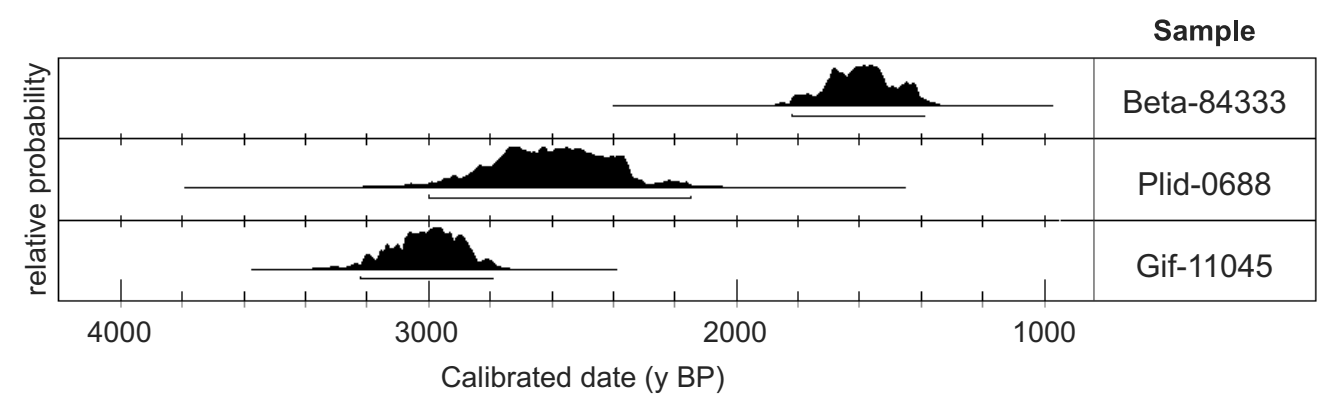

Fig. 4 - Probability distributions of calibration intervals (OxCal v3.10, Ramsey 1995) for the samples dated in this work (Gif-11045, Plid-0688) and a previously dated sample (Beta-84333, Buarque 1995). The total area under each curve is normalized to one (100\% probability).

sp, Tabebuia sp, Bombacaceae, Maytenus sp, Chrysobalanaceae, Euphorbiaceae, Lauraceae, Lecythidaceae, Cassia sp1, Cassia sp2, Copaifera sp, Myroxylon sp, Poecilanthe sp, Acacia sp, Inga sp, Piptadenia sp, Leguminosae, Melastomataceae, Trichilia sp, Myrtaceae, Sapotaceae, and Vochysia sp), and five taxa remained indeterminate. The sample contained only $1,6 \%$ of bark. Either the taxonomic diversity as the bark content are compatible with what is commonly found in dispersed charcoal at archaeological sediments, distinguishing it from usual hearth samples (for an in-depth discussion of these anthracological theoretical principles, see Scheel-Ybert 2004a, b).

This intrusive material is not related to natural events, such as a possible natural fire occurring over the abandoned site. Natural fire samples are taxonomically muchless diverse than archaeological ones (Scheel-Ybert et al. 2003a, Scheel-Ybert 2004a). The charcoal retrieved inside this urn is undoubtedly of anthropogenic origin, suggesting the site reoccupation along the time.

Recent archaeological data support this hypothesis, as there is evidence of modification in the material culture, especially in ceramics morphology, for Morro Grande site (A. Buarque, unpublished data). Archaeological researches in other regions also suggest that the same sites may have been reoccupied after centuries of abandon (Prous 1992). In Southern Brazil, there is evidence of reoccupation of the same regions along more than 1500 years, pointing to a large temporal persistence for the settlement territory (Noelli 1999/2000).

\section{CONCLUSION}

The age measurements reported for Morro Grande site considerably age the arrival of Tupian populations to the coastal region of Rio de Janeiro State. It is now certain that these populations entered the coast when it was yet heavily occupied by sambaqui moundbuilders, supporting the hypothesis that the structural changes observed in the social organization of the latter, and the consequent disruption of their sociocultural system, might be directly related to the arrival of ceramists (Buarque 1999, Scheel-Ybert et al. 2003b, Gaspar et al. 2004, BarbosaGuimarães 2007).

The occurrence of such an ancient dating in Southeastern Brazil may have important implications for the hypotheses about the origin and dispersion of Tupian populations from Amazonia. It supports the claim of recent authors who consider that the Tupian expansion must have begun well before 2000 yrs BP (Noelli 1998). However, the amount of age measurements for Tupiguarani sites is still insufficient to adequately give account of such an extensive expansion as the Tupian one. Currently, less than 250 dates are available for the entire Brazilian territory (Corrêa and Samia 2006). We believe the scarceness of research surely explains the lack of more ancient ages nearer to the origin of this dispersion, particularly in Amazonia. Over and above attesting of the earliest known Tupiguarani occupation in Brazil, our results point out to the imperative need of more systematic archaeological research either in local as in regional extent. 
It is highly important that the present data be considered in discussions about the Brazilian coastal occupation, but further research is still needed to bring up new data in order to validate or even dismiss the proposed hypotheses, either concerning the ancientness of the Tupiguarani occupation as the possibility of site reoccupation.

\section{ACKNOWLEDGMENTS}

R. Scheel-Ybert and R.M. Anjos are Conselho Nacional de Desenvolvimento Científico e Tecnológico (CNPq) fellowship holders. Scientific researches that made this paper possible are funded by $\mathrm{CNPq}$ and Fundação Carlos Chagas Filho de Apoio à Pesquisa do Estado do Rio de Janeiro (FAPERJ) projects.

\section{RESUMO}

Este artigo apresenta datações inesperadamente antigas para um assentamento Tupiguarani no sudeste do Brasil. Uma datação radiocarbono de $1740 \pm 90$ anos AP (1820-1390 cal anos AP) já existia para o sítio de Morro Grande, situado no município de Araruama, na costa sudeste do Estado do Rio de Janeiro. Duas novas datações, obtidas de amostras de carvão, são apresentadas neste trabalho. A data de $2920 \pm 70$ anos AP (3220-2790 cal anos AP) foi obtida a partir de uma fogueira de uso específico, provavelmente destinada a queimar cerâmica; uma outra provém de uma fogueira funerária do mesmo setor arqueológico, datada em $2600 \pm 160$ anos AP (3000-2150 cal anos AP). As duas medidas foram feitas independentemente, em laboratórios diferentes, o que reforça sua validade. Estas datações mostram que o momento de chegada de populações Tupiguarani à costa brasileira ocorreu muito antes do que se imaginava. Elas podem ter importantes implicações para as hipóteses sobre a origem e a dispersão dessas populações a partir da Amazônia, corroborando a hipótese de autores recentes que consideram que a expansão Tupi deve ter começado bem antes de 2000 anos AP.

Palavras-chave: datação radiocarbono, ocupação pré-histórica, Arqueologia, Tupiguarani, Brasil.

\section{REFERENCES}

BARbosa-Guimarães M. 2007. A ocupação pré-colonial na Região dos Lagos, RJ: sistema de assentamento e relações inter-societais entre grupos sambaquianos e grupos ceramistas Tupinambá e da Tradição Una. PhD Thesis, MAE-USP, $356 \mathrm{p}$.
Brochado J. 1989. A expansão dos Tupi e da cerâmica policrômica amazônica. Dédalo 27: 65-82.

Buarque A. 1995. Uma Aldeia Tupinambá em Morro Grande. In: Reunião Científica da Sociedade de Arqueologia Brasileira, 8, Porto Alegre. Anais..., 2: 207-220.

Buarque A. 1999. A Cultura Tupinambá no Estado do Rio de Janeiro. In: TENóRIo MC (Ed), Pré-História da Terra Brasilis. Rio de Janeiro: UFRJ, p. 307-320.

CORrÊA AA AND SAMIA DG. 2006. Cronologia da tradição arqueológica Tupiguarani. In: SIMPÓSIO INTERNAtional o Povoamento das AméricAs, 2, São Raimundo Nonato. Artigos e Resumos..., 10 p. Disponível em: <http://www.fumdham.org.br/simposio/artigos/

Danielle_Gomes_Artigo.pdf $>$. Acessado em 9 ago 2007.

DiAs O. 1994/1995. Considerações a respeito dos modelos de difusão da cerâmica Tupiguarani no Brasil. Rev Arqueol 8: 113-132.

FAusto C. 1992. Fragmentos de história e cultura Tupinambá: da etnologia como instrumento crítico de conhecimento etno-histórico. In: CUNHA MC (Ed), História dos Índios no Brasil. São Paulo: Cia das Letras/FAPESP, p. 381-396.

Gaspar mD, Tenorio MC, Buarque A, BarbosaGuimarães M, Oliveira JC AND SCheEl-Ybert R. 2004. Histórico e principais resultados do projeto de investigação: $\mathrm{O}$ aproveitamento ambiental das populações pré-históricas do Rio de Janeiro. Arq Mus Nacional 62: 103-129.

HeCKenBerger MJ. 1998. Manioc agriculture and sedentism in Amazonia: the Upper Xingu example. Antiquity 72: 633-648.

Heckenberger MJ, Neves EG And Petersen JB. 1998. De onde surgem os modelos? As origens e expansões Tupi na Amazônia Central. Rev Antropol 41: 69-96.

Lathrap DW. 1970. The Upper Amazon. London: Thames and Hudson, $256 \mathrm{p}$.

Maranca S. 1976. Estudo do sítio Aldeia da Queimada Nova, Estado do Piauí. Rev Mus Paulista, sér Arqueol 3: $1-103$.

McCormac FG, Hogg AG, Blackwell PG, Buck CE, Higham TFG AND REIMER PJ. 2004. SHCal04 Southern Hemisphere Calibration 0-11.0 cal kyr BP. Radiocarbon 46: 1087-1092.

MigliazZA EC. 1982. Linguistic prehistory and the refuge model. In: Prance GT (Ed), Amazonia: Biological diversification in the Tropics. New York: Columbia Univ Press, p. 497-519. 
Moraes CAM. 2007. Arqueologia Tupi no nordeste de São Paulo: um estudo de variabilidade artefatual. PhD Thesis, MAE-USP, $310 \mathrm{p}$.

Noelli F. 1998. The Tupi: explaining origin and expansions in terms of archaeology and of historical linguistics. Antiquity 72: 648-663.

NoElli F. 1999/2000. A ocupação humana na região sul do Brasil: Arqueologia, debates e perspectivas (1872-2000). Rev USP 44: 218-269.

Prous A. 1992. Arqueologia Brasileira. Brasília: UNB, $605 \mathrm{p}$.

RAMSEY CB. 1995. Radiocarbon calibration and analysis of stratigraphy: The OxCal program. Radiocarbon 37: 425-430.

[http://c14.arch.ox.ac.uk/embed.php?File=oxcal.html].

Rodrigues AD. 1964. Classificação do tronco lingüístico Tupi. Rev Antropol 12: 99-104.

Rodrigues AD. 2000. Hipóteses sobre as migrações dos três sub-conjuntos meridionais da família Tupi-Guarani. In: CONGRESSO NACIONAL DA AsSOCIAÇÃo BRASILEIRA DE LINGÜÍSTICA, 2, Florianópolis. Anais... CDROM.

SCATAMACCHIA MCM. 1990. A tradição policrômica no leste da América do Sul evidenciada pela ocupação Guarani e Tupinambá: fontes arqueológicas e etno-históricas. $\mathrm{PhD}$ Thesis, MAE-USP, $318 \mathrm{p}$.
SCHEEL-YBERT R. 2004a. Teoria e métodos em antracologia. 1. Considerações teóricas e perspectivas. Arq Museu Nacional 62: 3-14.

SCHEel-YBert R. 2004b. Teoria e métodos em antracologia. 2. Técnicas de campo e de laboratório. Arq Museu Nacional 62: 343-356.

SCHEEl-Ybert R, GOUVEIA SEM, PESSENDA LCR, Aravena R, Coutinho LM And Boulet R. 2003a. Holocene palaeoenvironmental evolution in the São Paulo State (Brazil), based on anthracology and soil $\delta^{13} \mathrm{C}$ analysis. The Holocene 13: 73-81.

Scheel-Ybert R, Eggers S, Wesolowski V, PetroNILHO CC, BOYADJIAN CH, DEBLASIS PAD, BARBOSA-Guimarães M AND GASPAR MD. 2003b. Novas perspectivas na reconstituição do modo de vida dos sambaquieiros: uma abordagem multidisciplinar. Rev Arqueol 16: 109-137.

URBAN G. 1996. On the geographical origins and dispersion of Tupian languages. Rev Antropol 39: 61-104.

Viveiros de CAstro E. 1996. Comentários ao artigo de F. Noelli. Rev Antropol 39: 55-60. 